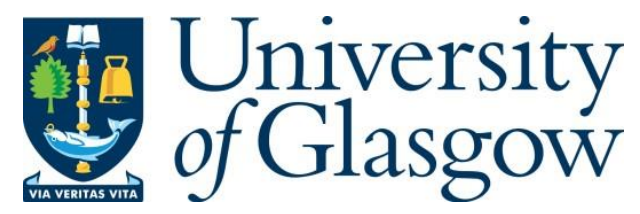

Knight, C. (2004) Liberal multiculturalism reconsidered. Politics, 24(3), pp. 189-197.

There may be differences between this version and the published version. You are advised to consult the publisher's version if you wish to cite from it.

http://eprints.gla.ac.uk/25835/

Deposited on: 14 July 2021

Enlighten - Research publications by members of the University of Glasgow http://eprints.gla.ac.uk 


\title{
Liberal Multiculturalism Reconsidered ${ }^{1}$
}

\author{
Carl Knight
}

\begin{abstract}
This article starts by setting out the evaluative criteria provided by Will Kymlicka's liberal account of individual freedom and equality. Kymlicka's theory of cultural minority rights is then analysed using these criteria and found to be defective in two respects. First, his assignment of different rights to national and ethnic groups is shown to be inegalitarian with regard to generations after the first. Second, his recommendation of strong cultural protections is shown in some circumstances to undermine freedom and equality. Towards the end of the paper a article of gradual and inclusive assimilation is described that may effectively promote the freedom and opportunities of members of cultural minorities. In conclusion, group-specific rights may, as Kymlicka says, be justified in liberal terms, but only where they differ in content from those he proposes.
\end{abstract}

\section{Introduction}

Western societies traditionally limited the rights of cultural minorities to the individual rights granted to all citizens. Multiculturalists claim that this fails to acknowledge the special problems facing such groups. Strikingly, Will Kymlicka reaches this conclusion from the perspective of a liberalism which places concern for the individual at its centre. His alternative is a multicultural theory that accommodates cultural diversity by means of group-differentiated rights.

Kymlicka's account of liberalism is derived from the work of John Rawls and Ronald Dworkin and, like these theorists' liberalism, is concerned above all with securing 
individual freedom and equality. Equality is invoked at various points of Kymlicka's argument and a conception of it is evident from these invocations. Most importantly, in considering the argument that group-specific rights are required to offset unfair disadvantages Kymlicka writes that external protections 'are clearly justified, I believe, within a liberal egalitarian theory, such as Rawls's and Dworkin's, which emphasizes the importance of rectifying unchosen inequalities' (Kymlicka 1995: 109; also 1989: ch. 9; see Rawls 1999; Dworkin 1981). As Kymlicka consistently accepts this as a justification for such protections I think it is clear that his account of liberalism only permits inequalities between individuals where those inequalities have arisen from those individual's choices.

According to Kymlicka's liberalism there are two preconditions for freedom. First, '[i]ndividuals must ... have the resources and liberties needed to live their lives in accordance with their beliefs about value' (Kymlicka 1995: 81; see Dworkin 1989). This prohibits attempts by society to impose beliefs or 'enforce morals'. Second, individuals must be allowed to question their own beliefs and values. Curiously Kymlicka restricts this requirement such that we individuals are only able 'to examine them [beliefs and values] in the light of whatever information, examples, and arguments our culture can provide' (1995: 81, emphasis added). Note that this second precondition for freedom seems to be weaker on Kymlicka's construal than the demands made by Rawls and Dworkin that Kymlicka cites in its support. Rawls, for example, says that 'citizens ... are regarded as, in general, capable of revising and changing' their conceptions of the good 'on reasonable grounds' - his restriction is one of reasonableness, not one of cultural specificity (1980: 544; see also Dworkin 1983). A full evaluation of one's values and 
beliefs is surely only possible where one is able to compare them with those held by members of other cultures (see Waldron 1995: 109; Parekh 2000: 226). In what follows I will evaluate Kymlicka's theory on the basis of the stronger construal of this precondition. This aspect alone of my critique of Kymlicka is external - though still very much from a liberal perspective.

In the next few sections we shall see how well Kymlicka's multicultural theory satisfies the criteria set down by these liberal principles of freedom and equality. Ultimately I will reject it and towards the end recommend a very different liberal strategy.

\section{National and ethnic group rights}

Kymlicka draws a distinction between different types of minority group that he says are due different types of 'group-differentiated right' (1995: ch. 2). The first are national minorities, who have traditional territorial claims and are granted robust external protections (see section III below) as they should 'have the opportunity to maintain themselves as a distinct culture' (1995: 113). These groups have a right to maintain their own societal culture - that is, 'a culture that provides its members with meaningful ways of life across the full range of human activities' (Kymlicka 1995: 76) This right entails subsidiary rights to self-government, language maintenance and a full set of social institutions. The second group are ethnic groups, who are immigrants, have no territorial claims and are not entitled to any such protection or political power. They merely receive support to allow them to integrate without disadvantage. (Kymlicka identifies political 
and economic refugees as further group types with distinct claims. I will not discuss these here.)

Kymlicka offers three justifications for the inequality of rights between national and ethnic groups. First, he claims that ethnic groups do not need stronger rights as 'their distinctiveness is manifested primarily in their family lives and in voluntary associations and is not inconsistent with their institutional integration' (Kymlicka 1995: 14). Second, he urges that granting ethnic groups stronger rights is impractical as existing groups are too dispersed and assimilated to form societal cultures (Kymlicka 1995: 96). Finally, he points out that many ethnic groups have entered the country on the expectation of integration: 'After all, most immigrants ... choose to leave their own culture. They have uprooted themselves, and they know when they come that their success, and that of their children, depends on integrating into the institutions of English speaking society' (1995: 95-6).

The first of these has some initial plausibility due to the fact that ethnic groups do generally make claims that are more easily integrated into the political system than national minorities' claims (Kymlicka 1995: 97-8). But this attempt at justification has significant shortfalls. In the first place, the claims and distinctiveness of ethnic groups could evidently be better secured were they in possession of self-government rights of the kind Kymlicka grants to national minorities. Ethnic groups do (contrary to Kymlicka's assertion) form institutions to support their members which could benefit from selfgovernment (Levey 1997: 217), while, say, religious exemptions from general legal requirements would be much more easily secured by ethnic minorities were they in possession of such rights. Moreover, even were the identification of two clusters of 
claims typically made - one by national minorities, the other by ethnic groups - accurate it would say nothing about the justifiability of such claims (Levy 1997: 50). Minorities only raise claims that they think might plausibly be assented to by dominant groups, and that assent has only a weak and contingent connection to what groups of individuals are due according to liberal principles.

Regarding the second justification, we might begin by stressing the different issues raised by dispersion and assimilation. The (half-)assimilated descendents of immigrants are clearly out of the picture. We then ask whether there are enough remaining ethnic group members in a particular geographical area to support the prerequisites of a societal culture. Although there is a tendency among some ethnic groups to congregate in certain areas of Western cities, this tendency has not been sufficient to give rise to territories in these cities of the size sufficient to support societal cultures. However, as with Kymlicka's first justification, we should be aware that citizens' behaviour is influenced by government policy. If a Western government announced that any (non-assimilated) ethnic group that constituted $x$ per cent of the population of a territory of $y$ thousand people would be entitled to self-government rights, it may be the case that this would be sufficient to pull enough members of an ethnic group to a certain area that a distinct societal culture there is tenable. Thus, Kymlicka's appeal to the fact that ethnic groups are dispersed implies a bias towards a state of affairs that may merely be the result of a policy that should itself be up for contention.

It seems, then, that the weight of justification must fall on the claim that ethnic groups have given up their rights to cultural protection. Bhikhu Parekh objects that '[s]ince culture is for Kymlicka a primary good, it is difficult to see how one can abandon 
one's right to it any more than to one's life or liberty' (2000: 103). But this lacks bite as it is having a culture which is a primary good for Kymicka, not having your original culture. It is true that he attaches great value to one's original culture as the foundation of self-identity, but in so doing his intent is only to oppose forced assimilation (Kymlicka 1989: 175-6). Hence Kymlicka does not say that ethnic groups waive their right to culture; they choose to use it to immerse themselves in a different culture.

The real problem with the second justification comes when we consider subsequent generations. As Kymlicka says, it seems reasonable to ask someone to integrate when they have chosen to enter the country on that expectation. But the descendents of immigrants have made no such choice. The difference in the rights granted to ethnic and national groups is less than compellingly grounded: in most cases the only difference between the two groups are their ancestors' statuses and decisions (Pogge 1997: 209-10; Mason 1999a: 110-1; Barry 2001: 218). Kymlicka effectively gives members of national minorities more rights and resources than ethnic groups, breaching the liberal prohibition on unchosen inequalities.

\section{Freedom, equality and cultural protection}

Kymlicka's theory of cultural rights distinguishes two varieties of such rights which are often claimed: those ensuring internal restrictions on group-members from within the group; and those ensuring external protections for the group as a whole from external encroachment (Kymlicka 1995: ch. 3). He maintains that in general external protections should be enforced, whilst claims for the right to impose internal restrictions should be rejected. 
On what basis does Kymlicka make this judgment? As explained above he holds that liberal freedom is concerned with the provision of choices and the ability to reconsider choices once made. He continues by saying that choice can only occur in a suitable context, the societal culture, which provides the options and gives them meaning by ascribing values to them relative to one another (Kymlicka 1995: ch. 5). The next stage has it that this context has to be one's own, original culture, for it is costly and difficult to change culture. From here it is easy to move to the conclusion that as liberal society is concerned with promoting freedom, and that freedom can only be exercised in each citizen's culture, each of the national groups in a multicultural society should have the right to state protection from external cultural forces. Dominant cultures, of course do not need such protection. But minority cultures may find their way of life eroded where market forces and social movements are left unchecked and consequently need protections to prevent such effects.

As the value Kymlicka attributes to minority cultures is in their role as choice contexts he 'precludes any system of internal restrictions which limit the right of individuals within the groups to revise their conception of the good' (1995: 161). Some multiculturalists argue that in so doing Kymlicka fails to acknowledge culture in any meaningful sense. William Galston, for example, claims that as many cultural groups do not value autonomy Kymlicka is demanding a 'forced shift of basic group identity' (1995: 523; Kukathas 1992: 120-4; Parekh 2000: 107-8). But a suitable liberal response would be that while unwanted changes in cultural identity may be required, these are a fair price to pay to pursue our goals of freedom and equality (Kymlicka 2001: 62). For the liberal cultural identity is, after all, only the means to those ends. 
An alternative objection is that granting special rights to cultural minorities gives them too much. Chandran Kukathas objects to Kymlicka on the grounds that there is no reason to grant special rights to cultural minorities given that many nonmembers - for example, the disabled and the poor - may be more disadvantaged than members (Kukathas 1992: 123). I think an adequate response is that all these groups get special rights appropriate to their disadvantage. The disabled get special rights to compensation for their disability, while the poor get special rights to economic equality. Kukathas' concern is perhaps understandable as Kymlicka does not make it very clear that these two other measures would have to be in place in order for the group-differentiated rights to avoid becoming the embodiment of a privileging of one type of disadvantage. But the spirit of Kymlicka's work converges with the liberal view that attributes equal priority to combating all unchosen inequalities. A further objection might be raised against special treatment generally, but that is an objection against this kind of liberalism itself.

\section{Problems with cultural protection}

It seems that if Kymlicka's argument about the relation between one's original culture and freedom works then cultural protections may be justified from a liberal perspective. But do the external protections required to sustain many minority cultures result in de facto internal restrictions? Kymlicka specifies that cultural contexts needs to be stable, for the fluctuations of options and value in an unstable context are too disorientating to facilitate individual's self-respect (1989: 165-6). This requirement is clarified by reference to a distinction between cultural structure (history, language, meanings) and character (norms, values, institutions); only the latter needs to be stable (Kymlicka 1989: 
166-70). However, the two sets of concepts appear to be necessarily coextensive. For example, "[i]f "norms and values" change then "meanings" change because norms and values are forms of meaning' (Bricker 1998: 52). Consequently once a stable culture is specified Kymlicka's argument appears to yield the strongly conservative conclusion that any threat of change to the character of a community gives rise to a valid claim to cultural protection (Tomasi 1995: 593). Where cultural stability is secured in this way the crucial liberal distinction between individual identity and cultural identity becomes blurred (Arthur 1999: 144). This undermines the first precondition for freedom noted at the outset, as members are discouraged from pursuing certain conceptions of the good. On its stronger interpretation the second precondition is also breached.

But have we moved too quickly to these conclusions? Kymlicka states that 'the cultural community continues to exist even where its members are free to modify the character of the culture, should they find its traditional ways of life no longer worth while' (Kymlicka 1989: 167). Evidently this freedom to modify cultural character amounts to little if it will always be overridden on the ground that that cultural structure is so fragile that it will become wholly unstable wherever cultural character changes. However, it is evident that cultural structures are not that fragile. Kymlicka provides the useful example of the liberalization of homosexuality laws in Britain (1989: 170). Clearly, such measures will over time change cultural character (norms and values) and, as Bricker notes, this will amount to a change in structure (meanings). That said, it would be outright bizarre to claim that this latter change amounts to such a structural upheaval that individuals are no longer able to assign values to their various options. So Kymlicka invites trouble by apparently making the character/structure distinction do the work. But 
his conclusions can be reached more directly, simply by stating that changes in character (= changes in structure) are acceptable provided they are moderate in their structural effects.

Unfortunately, some cultural structures cannot be held together without infringements of individuals' freedom. Consider the Canadian policies that prohibit the sale of aboriginal homelands by (aboriginal) individuals to outsiders (Kymlicka 1989: 146-8). Kymlicka explains that 'the viability of Indian communities depends on coercively restricting $\ldots$ both Indians and non-Indians' (1989: 146). The first condition of freedom is breached, for an Indian who wishes to pursue one of the many valuable life plans only achievable outside of the reservation can only do so by abandoning his home and receiving less than market value compensation ('a per capita share of the band's funds' [Kymlicka 1989: 148]). Even those who for the moment wish to pursue goals internal to the culture will have their freedom limited, for their powers to reassess such goals in accordance with the second condition of freedom will be restricted. This is because debates over the good will become radically parochialized by the artificial limits on cultural development that cultural protections introduce.

Kymlicka (1989: 147-8) makes a paternalist justification for these restrictions on freedom which fails. He says that the restriction is justified where in its absence Indians would sell their land because (1) they are so poor they need the money and/or (2) they are culturally ill-equipped and do not understand the consequences of doing so. But as Tomasi (1995: 596-8) implies, both these conditions can be avoided by the more rigorous application of the universal liberal principles of equality and freedom. If the aborigines were fairly provided for and liberally educated (1) and (2) would no longer pertain. It 
seems apparent, then, that restrictions such as these undermine freedom and fail to compensate for disadvantage any more effectively than universalistic liberal principles.

That cultural protections such as these infringe some members' freedom does not by itself mean that they are inappropriate. If they were the only viable way of securing a suitable choice context they may be a necessary evil. But they are not the only way, as I will now demonstrate.

\section{Assimilation}

I will now suggest that in some cases at least liberals ought to pursue policies of assimilation. Kymlicka offers two objections to assimilation which must be met at the outset. Firstly, he notes throughout his work that cultural minorities have historically opposed assimilation. But there are no historical examples of policies of assimilation being introduced against a backdrop of social and economic equality and nondiscrimination. Reference to the worse than chequered history of assimilationist policies towards North American Indians, for example, does little to undermine an assimilation grounded in the freedom and equality of all. Secondly, he argues that leaving one's culture may be possible, but it is hard, and is therefore not something we should expect someone to do (1995: 86). Although this suggests an effective rebuttal of Danley's (1991: 176-7) claim that members of cultural minorities should be held responsible for the consequences of their failure to transit to the dominant culture, it fails to account for gradual and accommodating processes of assimilation.

Given that, for the reasons noted, certain cultural protections should be off the agenda, we may expect some minority cultures to disintegrate. In these cases a policy of 
assimilation is clearly necessary in order to enable people to live fulfilling lives in the culture that they will inevitably find themselves (Raz 1986: 424; Levy 2000: 121). But even where disintegration is not in progress there may be a strong case for assimilation where there are simply more opportunities in mainstream society. This has major ramifications as there often will be more opportunities. Not only are the dominant cultures in Western countries per capita more conducive to freedom than many minority cultures, but even where the minority cultures are equal in this regard there will usually be more opportunities in dominant cultures to revise values, beliefs and life-goals (in accordance with the second precondition of freedom) due to the sheer number of ideas and options that their greater scale provides. ${ }^{2}$ Thus government policies that go beyond Parekh's (2000: 221-2) proposal to equalize the conditions of 'intercultural interaction' may be required, for without them some citizens will continue to be under cultural conditions that disadvantage them.

The best case for assimilation regards upcoming generations where educational measures may be taken to ease cultural transitions (Levy 2000: 120). In this case the test of consent some propose (Anaya 1997: 228) as a measure of fair assimilation seems inapplicable. It is not very relevant here, as Kymlicka supposes, that the current adult generation usually oppose such moves. Liberals cannot accept limitations on one generation's prospects imposed by another generation. Furthermore, assimilation from an early age eliminates the disadvantage of 'coming into the game after it has already begun' (Young 1990: 164).

From the liberal perspective the only strong countervailing force is the strain this might place on self-identity, particularly for the first assimilated generations. They may 
either find it hard to identify with older friends and relatives or, due to their identification with friends and relatives, fail to assimilate. But these are not knockdown dangers for assimilation; rather, they suggest two strategies. Firstly, assimilation should be carried out in a slow and sensitive fashion, possibly over several generations. To begin with, policies of political or civic assimilation that leave cultural variations intact may be introduced and the minority language accepted in public discourse. The minority language may then be gradually phased out of use in public institutions, and educational measures taken to fully integrate the children of members of minority culture in the social institutions of the larger culture. Andrew Mason notes that 'if a policy of assimilation has as its effects the gradual erosion of minority cultures, accompanied by a gradual transformation in the identities of their members so that they can identify more and more with the dominant culture, it is unclear if they face significant unchosen disadvantages' (1999b: 271). It is also important that the process is transparent and open to public debate and that its purpose - to increase members' freedom - is apparent.

Secondly, the culture to which ex-minority members are assimilated should retain awareness of and pride in the diversity of its cultural heritage (Barry 2001: 233-8). Historical and social education in schools would play an important role, and many vestiges of cultural identity, parallel to those of young Irish or Italian Americans, may remain and be publicly supported. This takes us towards Jeremy Waldron's (1995) 'cosmopolitan alternative' which draws meaning and value from a variety of cultures. Kymlicka's (1995: 85) complaint that Waldron is merely describing 'the diverse societal culture which characterises the Anglophone society of the United States' is neither here nor there. From the liberal perspective what matters here is freedom; if members of 
cultural minorities would be freer were they assimilated into an inclusive mainstream culture then so be it.

\section{Conclusion}

I have defended on liberal principles the multiculturalist belief that cultural diversity may require special rights in order for cultural disadvantages to be fairly compensated. But the particular allocation of group-specific rights which I have said to be supportive of liberal principles diverges in two ways from those recommended from a similar perspective by Kymlicka. First, those rights should be granted to national and (after the first generation) ethnic groups alike. Second, those rights should not include rights of cultural protection where freedom and equality are better served by a right of assimilation, to be exercised either by adult members or by the state on behalf of non-adult members. To some these conclusions will seem to be a step back for liberal multiculturalism. But if I have been correct in my various arguments it is for the liberal a step back from the abyss.

\section{Bibliography}

Anaya, S. J. (1997) 'On justifying special ethnic group rights: comments on Pogge' in I. Shapiro and W. Kymlicka (eds.) Nomos XXXIX: Ethnicity and Group Rights, New York: New York University Press.

Arneson, R. J. (1989) 'Equality and equal opportunity for welfare', Philosophical Studies, 56, 77-93.

Arthur, J. (1999) 'Identity and multicultural politics' in R. Bellamy and M. Hollis (eds.) Pluralism and Liberal Neutrality, London: Frank Cass.

Barry, B. (2001) Culture and Equality: An Egalitarian Critique of Multiculturalism, Cambridge: Polity.

Bricker, D. C. (1998) 'Autonomy and culture: Will Kymlicka on cultural minority rights', The Southern Journal of Philosophy, 36, 47-59.

Cohen, G. A. (1989) 'On the currency of egalitarian justice' Ethics, 99, 906-44.

Danley, J. R. (1991) 'Liberalism, aboriginal rights, and cultural minorities', Philosophy and Public Affairs, 20, 168-85. 
Dworkin, R. (1981) 'What is equality? Part 2: Equality of resources', Philosophy and Public Affairs, 10, 283-345.

Dworkin, R. (1983) 'Comment on Narveson: In defense of equality', Social Philosophy and Policy, 1, 24-40.

Dworkin, R. (1989) 'Liberal community', California Law Review, 77, 479-504.

Galston, W. (1995) 'Two concepts of liberalism', Ethics, 105, 516-34.

Kukathas, C. (1992) 'Are there any cultural rights?', Political Theory, 20, 105-39.

Kymlicka, W. (1989) Liberalism, Community, and Culture, Oxford: Oxford University Press.

Kymlicka, W. (1995) Multicultural Citizenship: A Liberal Theory of Minority Rights, Oxford: Oxford University Press.

Kymlicka, W. (2001) Politics in the Vernacular (Oxford: Oxford University Press).

Levey, G. B. (1997) 'Equality, autonomy, and cultural rights', Political Theory, 25, 21548.

Levy, J. T. (1997) 'Classifying cultural rights' in W. Kymlicka \& I. Shapiro (eds.) Nomos XXXIX: Ethnicity and Group Rights, New York: New York University Press.

Mason, A. (1999a) 'Imposing liberal principles' in R. Bellamy and M. Hollis (eds.) Pluralism and Liberal Neutrality, London: Frank Cass.

Mason, A. (1999b) 'Political community, liberal-nationalism, and the ethics of assimilation', Ethics, 109, 261-86.

Parekh, B. (2000) Rethinking Multiculturalism: Cultural Diversity and Political Theory, Basingstoke: Palgrave.

Pogge, T. W. (1997) 'Group rights and ethnicity' in W. Kymlicka \& I. Shapiro (eds.) Nomos XXXIX: Ethnicity and Group Rights, New York: New York University Press.

Rawls, J. (1980) 'Kantian Constructivism in Moral Theory', The Journal of Philosophy, 77, 515-7.

Rawls, J. (1999) A Theory of Justice, revised edition, Oxford: Oxford University Press. Raz, J. (1986) The Morality of Freedom, Oxford: Oxford University Press.

Tomasi, J. (1995) 'Kymlicka, liberalism, and respect for cultural minorities', Ethics, 105, 580-603.

Waldron, J. (1995) 'Minority cultures and the cosmopolitan alternative' in W. Kymlicka (ed.) The Rights of Minority Cultures, Oxford: Oxford University Press.

Young, I. R. (1990) Justice and the Politics of Difference, Princeton: Princeton University Press. 
${ }^{1}$ This is a pre-publication version of Carl Knight, 'Liberal Multiculturalism Reconsidered', Politics, 24 (2004), 189-197. The published version is available at https://doi.org/10.1111/j.1467-9256.2004.00219.x The author would like to thank Catriona McKinnon and two anonymous referees for their helpful comments on antecedents of this paper. Research for this paper was supported by the University of York Alumni Fund.

${ }^{2}$ Note that the argument works equally well where there are two or more larger cultures - for example Anglophone and Francophone Canada - each of which offers greater opportunities than the smaller culture. 